University of Nebraska - Lincoln

DigitalCommons@University of Nebraska - Lincoln

Biological Systems Engineering: Papers and Publications

1994

\title{
Moisture Adsorption by Grain Protein Films
}

\author{
A. Gennadios \\ University of Nebraska-Lincoln, aris.gennadios@catalent.com \\ Curtis L. Weller \\ University of Nebraska-Lincoln, cweller1@unl.edu
}

Follow this and additional works at: https://digitalcommons.unl.edu/biosysengfacpub

Part of the Biological Engineering Commons

Gennadios, A. and Weller, Curtis L., "Moisture Adsorption by Grain Protein Films" (1994). Biological Systems Engineering: Papers and Publications. 92.

https://digitalcommons.unl.edu/biosysengfacpub/92

This Article is brought to you for free and open access by the Biological Systems Engineering at DigitalCommons@University of Nebraska - Lincoln. It has been accepted for inclusion in Biological Systems Engineering: Papers and Publications by an authorized administrator of DigitalCommons@University of Nebraska Lincoln. 


\title{
Moisture Adsorption by Grain Protein FiLMS
}

\author{
A. Gennadios, C. L. Weller \\ StUdent MeMBer Member \\ ASAE ASAE
}

\begin{abstract}
Grain protein films plasticized with glycerol were prepared from corn zein (CZ), wheat gluten (WG), and a 2.3:1 mixture of wheat gluten and soy protein isolate (WG/SPI). Moisture adsorption curves of the three types of protein films at $25^{\circ} \mathrm{C}$ and within an approximate water activity range of 0.11 to 0.84 were obtained using a static gravimetric method. The Smith, Oswin, Halsey, and Guggenheim-Anderson-de Boer (GAB) models were applied to collected data. For all protein films, the GAB model showed the best fit over the entire studied water activity range yielding mean deviation modulus values $(P)$ of 4.69, 3.44, and 7.95 for WG, WG/SPI, and CZ films, respectively. The Smith and Halsey models fitted well the high water activity (0.53 to 0.84) portion of the isotherms with $P$ values ranging between 2.55 and 6.74. Moisture adsorption behavior by the protein films at the low water activity range $(0.11$ to 0.58$)$ was reasonably well described by the Oswin model (P values of 6.68, 5.25, and 5.24 for WG, WG/SPI, and CZ films, respectively).
\end{abstract}

Keywords. Protein films, Moisture adsorption, Corn zein, Wheat gluten, Soy protein.

$\mathrm{E}$ dible biopolymer films and coatings derived from protein, polysaccharide, and lipid materials have been investigated for potential applications in food packaging and food preservation. Edible film formation mechanisms, production methods, and properties have been comprehensively reviewed (Guilbert, 1986, 1988; Kester and Fennema, 1986; Krochta, 1992). Detailed discussions on protein films in particular have also been published (Gennadios and Weller, 1990, 1991; Gennadios et al., 1993a). Several recent studies have reported information on mechanical and barrier properties of protein films from wheat gluten (Park and Chinnan, 1990; Aydt et al., 1991; Gennadios and Weller, 1992; Gennadios et al., 1993b, c, d, e, 1994; Gontard et al., 1992, 1993), corn zein (Park and Chinnan, 1990; Aydt et al., 1991; Gennadios et al., 1993d, 1994; Trezza et al., 1992), and soy protein isolate (Gennadios et al., 1993e; Brandenburg et al., 1993). In all the aforementioned studies, film preparation involved casting protein dispersions in water or aqueous ethanol with subsequent drying. A plasticizer, usually glycerol, was added to ensure production of self-supporting films.

In general, protein films are poor water vapor barriers due to the inherent hydrophilicity of protein. However, protein films were found to be very effective oxygen barriers (Brandenburg et al., 1993; Gennadios et al., 1993d). Use as oxygen barrier-providing layers in

Article was submitted for publication in July 1993; reviewed and approved for publication by the Food and Process Engineering Inst. of ASAE in February 1994. Presented as ASAE Paper No. 91-6524.

Technical contribution No. 3447 of the South Carolina Agricultural Experiment Station, Clemson University, Clemson.

The authors are Aristippos Gennadios, Graduate Research Assistant, and Curtis L.Weller, Assistant Professor, Dept. of Biological Systems Engineering, University of Nebraska, Lincoln (both formerly with the Dept. of Agricultural and Biological Engineering at Clemson University, Clemson, S.C.). multilayer or multicomponent packaging materials, and as coatings for oxygen-sensitive food items in combination with an external efficient moisture barrier constitute examples of potential protein film applications.

Physical and barrier properties of hydrophilic protein films can be significantly influenced by the moisture concentration in the films (Gontard et al., 1993; Gennadios et al., 1994). For example, the tensile strength of corn zein films conditioned for two days at $25^{\circ} \mathrm{C}$ and 23 or $75 \%$ relative humidity was 19.5 and $5.7 \mathrm{MPa}$, respectively (Gennadios et al., 1994). Similarly, wheat gluten films conditioned for two days at $25^{\circ} \mathrm{C}$ and 23 or $75 \%$ relative humidity had tensile strength values of 5.2 and 2.7 MPa, respectively (Gennadios et al., 1994). According to Watt (1983), water vapor sorption by biopolymers may result in swelling and conformational changes of the macromolecular structure. Consequently, an understanding of the water sorption properties of edible protein films is necessary in order to tailor their application on or in food systems. Experimentally derived moisture sorption isotherms would offer a useful tool for estimating moisture content of a film at equilibrium with a given relative humidity environment.

The present study was undertaken to develop the moisture adsorption isotherms at $25^{\circ} \mathrm{C}$ of three different types of laboratory-produced grain protein edible films. The three films were made from wheat gluten, corn zein, and a 2.3:1 mixture of wheat gluten and soy protein isolate. Mathematical models of water sorption isotherms were applied on collected experimental data and tested for accuracy of fit.

\section{Materials AND METHOdS \\ Preparation of Film-Forming Solutions}

Vital wheat gluten protein (DO-PEP), soy protein isolate (PP 620), and corn zein (F-4000) protein were obtained from ADM Arkady (Olathe, Kans.), Protein 
Technologies International (St. Louis, Mo.), and Freeman Industries (Tuckahoe, N.Y.), respectively. Film-forming solutions for the wheat gluten (WG) films consisted of $15 \mathrm{~g}$ WG, $72 \mathrm{~mL} \mathrm{95 \%} \mathrm{ethanol,} 6 \mathrm{~g}$ glycerol, $12 \mathrm{~mL} 6 \mathrm{~N}$ ammonium hydroxide, and $48 \mathrm{~mL}$ distilled water (Gennadios et al., 1993b, c). Wheat gluten/soy protein isolate (WG/SPI) films had similar composition except that $4.5 \mathrm{~g}$ of wheat gluten were substituted with soy protein isolate (Gennadios et al., 1993c). Corn zein (CZ) filmforming solutions were prepared by mixing $10 \mathrm{~g} \mathrm{CZ}, 2 \mathrm{~g}$ glycerol, and $65 \mathrm{~mL} 95 \%$ ethanol. All film-forming solutions were heated for $10 \mathrm{~min}$ under stirring. Heating rate was adjusted so that at the end of preparation the solutions had a temperature of 75 to $77^{\circ} \mathrm{C}$.

\section{Film Casting and DRYing}

Film-forming solutions, while still hot, were cast on flat glass plates with a thin-layer chromatography spreader bar (Brinkman Co., New York, N.Y.) set at $1.5 \mathrm{~mm}$. Casting areas on plates were "framed" with a layer of masking tape to restrain solution spreading. Plates with cast solutions were placed in an air-circulating oven (Isotemp, model 338 F, Fisher Scientific, Pittsburgh, Pa.) maintained at $35^{\circ} \mathrm{C}$. After $15 \mathrm{~h}$, the plates were removed from the oven and the films were peeled off.

\section{FILM ThiCKNESS}

Film thickness was measured with a hand-held micrometer (B.C. Ames Co., Waltham, Mass.) to the nearest $2.54 \mu \mathrm{m}(0.1 \mathrm{mil})$. Thickness values for each type of film, representing an average of 30 measurements, were $80 \pm 18,122 \pm 15$, and $132 \pm 12 \mu \mathrm{m}$ for $\mathrm{CZ}, \mathrm{WG}$, and WG/SPI films, respectively.

\section{Chemical Analysis}

The three types of film were chemically analyzed by the Department of Agricultural Chemical Services, Clemson University. The dry matter of film samples was determined after freeze-drying at $-60^{\circ} \mathrm{C}$ and $1.33 \mathrm{~Pa}$ (10 milliTorr). Crude protein was determined with a micro-Kjeldahl method, using a nitrogen conversion factor of 5.70 for WG and WG/SPI films, and of 6.25 for CZ films. Ashing of samples was done in a muffle furnace at $600^{\circ} \mathrm{C}$ for $4 \mathrm{~h}$. Crude fat contents were determined after extraction with hexane in a Soxhlet apparatus overnight. Carbohydrate contents were estimated by difference. All tests were done in triplicate for each type of film. Results, on a dry basis, are presented in table 1 .

\section{Determination of Moisture Adsorption}

Constant relative humidity environments were established inside sorbostats, one-pint wide mouth canning jars, using saturated salt solutions. The salts used (table 2) were the 10 different salts recommended by the COST-90 project (Wolf et al., 1984), covering a relative humidity (RH) range from 11.15 to $90.26 \%$. Water activity $\left(a_{w}\right)$ for the films was defined as \%RH/100 (Labuza, 1968). Film samples were assumed to have a $\mathrm{a}_{\mathrm{w}}$ corresponding to the $\mathrm{RH}$ of the sorbostat and to reach an equilibrium moisture content within each sorbostat.

Prior to beginning adsorption tests, film samples were cut into small pieces (approximately $5 \times 5 \mathrm{~mm}$ ). They were then brought to zero moisture content by freeze-drying at
Table 1. Percent chemical composition (dry basis) of grain protein films*

\begin{tabular}{lcccc}
\hline Film & Crude Protein & Crude Fat & Ash & Carbohydrate \\
\hline CZ & $78.25 \pm 0.32$ & $0.52 \pm 0.26$ & $1.15 \pm 0.11$ & $20.07 \pm 0.35$ \\
WG & $53.07 \pm 0.52$ & $1.76 \pm 0.33$ & $0.50 \pm 0.04$ & $44.67 \pm 0.56$ \\
WG/SPI & $54.13 \pm 0.40$ & $1.74 \pm 0.72$ & $1.35 \pm 0.06$ & $42.79 \pm 0.36$ \\
\hline
\end{tabular}

* Reported values are means of three replicates plus/minus one standard deviation.

$-55^{\circ} \mathrm{C}$ and $0.67 \mathrm{~Pa}$ (5 milliTorr) for $24 \mathrm{~h}$ (Lyph-Lock 12, Labconco Co., Kansas City, Mo.). Samples of $0.4 \mathrm{~g}$ of all films were weighed and placed into aluminum pans, $5 \mathrm{~cm}$ in diameter. The aluminum pans which contained the samples were suspended over the sorbate in the sealed sorbostats. The sorbostats were kept inside an environmental chamber maintained at $25^{\circ} \mathrm{C}$. The pans had been equilibrated in the sorbostats for two days before their tare weights were recorded.

The weights of samples were recorded to the nearest $0.0001 \mathrm{~g}$ after the first two days and every day thereafter until equilibrium. Equilibrium was assumed to have been reached when the change in moisture content of samples was less than $0.001 \mathrm{~g}$ water/g dry matter (Labuza, 1984). Equilibrium was observed after one week for the first nine salts (RH range 11.15 to $84.32 \%$ ). Material deterioration was evidenced, from mold growth and putrid smell, for all samples placed over the salt with the highest RH (90.26\%), before equilibrium was reached. Therefore, equilibrium moisture contents at this $\mathrm{RH}$ are not reported. Results at equilibrium were reported for each relative humidity as gram water adsorbed/gram dry matter. Adsorption tests were done in triplicate for each type of film at each relative humidity.

\section{Mathematical Models}

The four different models for fitting water sorption isotherms of food products which are presented in table 3 were evaluated for accuracy of fit on the experimental data.

\section{Model Parameters and Accuracy of Fit}

Experimental sorption data for each type of film were fitted to the above mathematical models using a nonlinear regression analysis procedure (NLIN) in a SAS statistical package (SAS Institute, Inc., 1988). The procedure was

Table 2. Preparations of saturated salt solutions at $25^{\circ} \mathrm{C}$ (Wolf et al., 1984)

\begin{tabular}{lccc}
\hline & & \multicolumn{2}{c}{ Mixing Analogy } \\
\cline { 3 - 4 } Salt & $\begin{array}{c}\text { Relative Humidity } \\
(\%)\end{array}$ & $\begin{array}{c}\text { Salt } \\
(\mathrm{g})\end{array}$ & $\begin{array}{c}\text { Distilled Water } \\
(\mathrm{mL})\end{array}$ \\
\hline $\mathrm{LiCl}$ & 11.15 & 75 & 42.5 \\
$\mathrm{CH}_{3} \mathrm{COOK}$ & 22.60 & 100 & 32.5 \\
$\mathrm{MgCl}_{2}$ & 32.73 & 100 & 12.5 \\
$\mathrm{~K}_{2} \mathrm{CO}_{3}$ & 43.80 & 100 & 45.0 \\
$\mathrm{Mg}$ & 52.86 & 100 & 15.0 \\
$\left.\mathrm{NaBr}_{3}\right)$ & 57.70 & 100 & 40.0 \\
$\mathrm{SrCl}_{2}$ & 70.83 & 100 & 25.0 \\
$\mathrm{NaCl}_{\mathrm{KCl}}$ & 75.32 & 100 & 30.0 \\
$\mathrm{KCl}_{\mathrm{BaCl}}$ & 84.32 & 100 & 40.0 \\
\hline
\end{tabular}


Table 3. Moisture sorption isotherm models fitted to experimental adsorption data of edible grain protein films

\begin{tabular}{lll}
\hline Name & Model* $^{*}$ & Reference \\
\hline Smith & $M=A-\left[B \ln \left(1-a_{w}\right)\right]$ & Smith (1947) \\
Oswin & $M=A\left[a_{w} /\left(1-a_{w}\right)\right]^{B}$ & Oswin (1946) \\
Halsey & $M=\left[-A /\left(T \ln a_{w}\right)\right]^{1 / B}$ & Halsey (1948) \\
GAB & $M=\left(M_{0} C\left(k a_{w}\right) /\left[\left(1-k a_{w}\right)\left(1-k a_{w}+C k a_{w}\right)\right]\right.$ & Bizot (1984) \\
\hline
\end{tabular}

* $\quad M=$ equilibrium moisture content (g water/g dry solids); $a_{w}=$ water activity; $\mathrm{T}$ = absolute temperature (K); $\mathrm{A}=$ constant; $\mathrm{B}=$ constant; $\mathbf{M}_{\mathrm{o}}=$ monolayer moisture content ( $\mathrm{g}$ water/g dry solids); $\mathrm{C}=$ Guggenheim constant; and $\mathrm{k}=$ constant correcting the properties of the multilayer molecules with respect to the bulk liquid.

$\dagger$ As simplified by Chirife and Iglesias (1978).

$\ddagger$ Guggenheim-Anderson-de Boer.

used with the iterative modified Gauss-Newton method to regress the residuals onto the partial derivatives of the model with respect to the parameters, until the parameter estimates converge.

The criterion used to evaluate accuracy of fit for each model was the mean relative deviation modulus (P) calculated by the expression:

$$
P=(100 / n) \Sigma\left(\left|M_{a}-M_{p}\right| / M_{a}\right)
$$

where $M_{a}$ is the actual (experimental) moisture content; $M_{p}$ is the predicted moisture content; and $n$ is the number of observations. A $P$ value smaller than 5 indicates an extremely good fit; a $\mathrm{P}$ value between 5 and 10 represents a reasonably good fit; and a $P$ value greater than 10 shows a poor fit (Lomauro et al., 1985a, b; Gencturk et al., 1986).

\section{RESULTS AND DISCUSSION MoISTURE ADSORPTION}

Experimental data for moisture adsorption at $25^{\circ} \mathrm{C}$ for $\mathrm{CZ}$, WG, and WG/SPI films are shown in figure 1 . Both WG and WG/SPI films had higher equilibrium moisture contents than $\mathrm{CZ}$ films at all water activities covered. This observation was mainly attributed to the lower amount of hygroscopic glycerol incorporated in CZ films $(20 \mathrm{~g} / 100 \mathrm{~g}$ protein) than in WG and WG/SPI films $(40 \mathrm{~g} / 100 \mathrm{~g}$

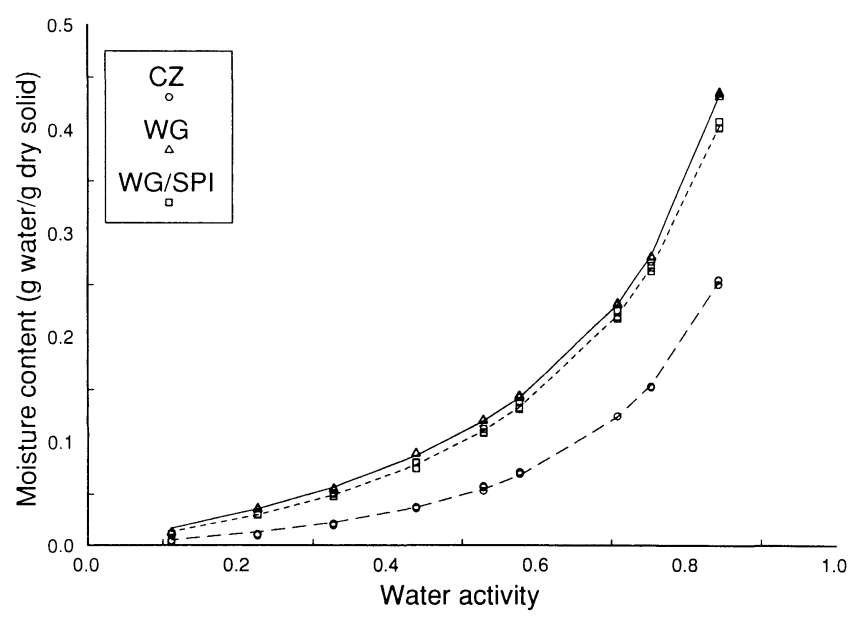

Figure 1-Experimental data points and isotherm curves predicted by the GAB model for moisture adsorption by $\mathrm{CZ}$, WG, and WG/SPI films at $25^{\circ} \mathrm{C}$.
Table 4. Mean relative $P$ and constants $\left(M_{0}, C\right.$, and $\left.k\right)$ of the $G A B$ moisture isotherm equation for moisture adsorption of edible grain protein films at $25^{\circ} \mathrm{C}$

\begin{tabular}{lllllll}
\hline Film & $\mathrm{a}_{\mathrm{w}}$ Range & $\mathrm{n}^{*}$ & $\mathrm{P}$ & $\mathrm{M}_{\mathrm{o}}$ & $\mathrm{C}$ & $\mathrm{k}$ \\
\hline CZ & $0.11-0.84$ & 27 & 7.95 & 0.1241 & 0.3456 & 0.8899 \\
CZ & $0.33-0.84$ & 21 & 3.37 & 0.1027 & 0.9333 & 0.9072 \\
WG & $0.11-0.84$ & 27 & 4.69 & 0.1052 & 1.3333 & 0.9450 \\
WG & $0.33-0.84$ & 21 & 1.21 & 0.1023 & 1.4111 & 0.9490 \\
WG/SPI & $0.11-0.84$ & 27 & 3.44 & 0.1386 & 0.8088 & 0.8959 \\
WG/SPI & $0.33-0.84$ & 21 & 1.75 & 0.1351 & 0.8376 & 0.8993 \\
\hline
\end{tabular}

* Number of experimental data points.

protein). Furthermore, $\mathrm{CZ}$ is characterized by a low content of polar (hydrophilic) amino acids and a high content of nonpolar (hydrophobic) amino acids, such as leucine, proline, and alanine (Shewry and Miflin, 1985). Reportedly, CZ has a higher hydrophobicity, as calculated by amino acid composition, than the prolamin and glutelin protein fractions of WG and other cereals (Belitz et al., 1986).

The WG/SPI films had slightly lower equilibrium moisture contents than WG films at all $\mathrm{a}_{\mathbf{w}}$ studied. Water vapor permeability constant values for WG and WG/SPI films, identical to the ones produced in this study, were reported by Gennadios et al. (1993c). Water vapor permeability, which consists of water sorption into and diffusion through a barrier, is a measure of a film's hydrophilicity. Gennadios et al. (1993c) found that the WG/SPI film had a lower, although not statistically significantly different, water vapor permeability constant value than the WG film.

\section{MOISTURE ISOTHERM EQUATIONS}

The four moisture isotherm mathematical models (Smith, Oswin, Halsey, and GAB) were fitted to moisture adsorption data for the whole water activity range studied and for specific portions of that range. Calculated model constants and mean relative deviation modulus for each case are shown in tables $4,5,6$, and 7 for the GAB, Smith, Oswin, and Halsey models, respectively.

For all three types of films, the GAB model showed the best fit over the whole isotherms [see the relative deviation modulus (P) in tables 4 through 7]. It fitted very well for the WG and the WG/SPI films $(P=4.69$ and 3.44 , respectively) and reasonably well for the $\mathrm{CZ}$ film $(P=7.95)$. The fit of the GAB model was even better when applied over the $\mathrm{a}_{\mathrm{w}}$ range from 0.33 to 0.84 . Chirife et al. (1992) reported that the constant $k$ in the GAB sorption model varies from nearly unity to as low as 0.56 for a large

Table 5. Mean relative $P$ and constants $(A$ and $B$ ) of the Smith moisture isotherm equation for moisture adsorption of edible grain protein films at $25^{\circ} \mathrm{C}$

\begin{tabular}{lllrll}
\hline Film & $\mathrm{a}_{\mathrm{w}}$ Range & n* & \multicolumn{1}{l}{$\mathrm{P}$} & $\mathrm{A}$ & $\mathrm{B}$ \\
\hline CZ & $0.11-0.84$ & 27 & 85.34 & -0.0356 & 0.1411 \\
CZ & $0.53-0.84$ & 15 & 6.74 & -0.0843 & 0.1772 \\
WG & $0.11-0.84$ & 27 & 33.06 & -0.0396 & 0.2361 \\
WG & $0.53-0.84$ & 15 & 5.08 & -0.1026 & 0.2826 \\
WG/SPI & $0.11-0.84$ & 27 & 36.81 & -0.0401 & 0.2239 \\
WG/SPI & $0.53-0.84$ & 15 & 3.56 & -0.0966 & 0.2658 \\
\hline
\end{tabular}

* Number of fitted experimental data points. 
Table 6. Mean relative $P$ and constants (A and $B$ ) of the Oswin moisture isotherm equation for moisture adsorption of edible grain protein films at $25^{\circ} \mathrm{C}$

\begin{tabular}{lllrll}
\hline Film & $\mathrm{a}_{\mathrm{w}}$ Range & n* & \multicolumn{1}{l}{$\mathrm{P}$} & $\mathrm{A}$ & $\mathrm{B}$ \\
\hline CZ & $0.11-0.84$ & 27 & 20.05 & 0.0510 & 0.9626 \\
CZ & $0.11-0.58$ & 18 & 5.24 & 0.0485 & 1.2243 \\
WG & $0.11-0.84$ & 27 & 10.07 & 0.1095 & 0.8254 \\
WG & $0.11-0.58$ & 18 & 6.68 & 0.1086 & 0.9250 \\
WG/SPI & $0.11-0.84$ & 27 & 13.82 & 0.1020 & 0.8307 \\
WG/SPI & $0.11-0.58$ & 18 & 5.25 & 0.0990 & 0.9799 \\
\hline
\end{tabular}

* Number of fitted experimental data points.

variety of food constituents, while $\mathrm{k}$ values for proteins fall in the range of 0.82 to 0.88 . The higher $\mathrm{k}$ values calculated for the grain protein films in the present study most likely resulted from the large amount of glycerol (20 to $40 \% \mathrm{w} / \mathrm{w}$ of protein) added to films.

The GAB water sorption isotherm model is the most popular one in the area of food technology, fitting moisture sorption data extremely well for many food materials over a wide range of $\mathrm{a}_{\mathrm{w}}$, up to 0.9 (Bizot, 1984). Lomauro et al. $(1985 \mathrm{a}, \mathrm{b})$ found that the GAB model gave a very good fit $(\mathrm{P}<5)$ for over $50 \%$ of 75 food isotherms representing fruit, vegetable, and meat food products and over $75 \%$ of 88 isotherms representing milk, coffee, tea, nuts, oilseeds, spices, and starchy foods. A good fit of the GAB model was also reported for isotherms of wild rice at temperatures ranging from 10 to $43.5^{\circ} \mathrm{C}$ (Gencturk et al., 1986); raisins and dried apricots at $20^{\circ} \mathrm{C}$ (Ayranci et al., 1990); and dried fruits (raisins, currants, figs, prunes, and apricots) at 15, 30, 45 , and $60^{\circ} \mathrm{C}$ (Tsami et al., 1990).

The Smith model was proven to fit the high $\mathrm{a}_{\mathrm{w}}$ portions of water sorption isotherms of various biopolymers (Smith, 1947). A good fit of the Smith model was also documented for adsorption and desorption isotherms of Virginia-type peanuts above $a_{w}$ of 0.30 (Young, 1976); desorption isotherms of wheat between $a_{w}$ of 0.50 and 0.95 (Becker and Sallans, 1956); and adsorption isotherms of cowpeas at the high $\mathrm{a}_{\mathrm{w}}$ portion of the curves (Chinnan and Beuchat, 1985). Pixton and Howe (1983) reported that the Smith model gave a satisfactory fit for water sorption curves of several food commodities including field beans, dried peas, dried figs, and rice bran. In the present study, for $a_{w}$ in the range of 0.53 to 0.84 , the Smith model fitted adsorption data of WG $(P=5.08)$ and WG/SPI $(P=3.36)$ films well and data of $\mathrm{CZ}$ films $(\mathrm{P}=6.78)$ reasonably well (table 5). Fit to the data for the whole range of $a_{w}$ was very poor.

The Oswin model was found very suitable to describe sorption isotherms of proteins and starchy foods

Table 7. Mean relative $P$ and constants (A and $B$ ) of the Halsey moisture isotherm equation for moisture adsorption of edible grain protein films at $25^{\circ} \mathrm{C}$

\begin{tabular}{lllrll}
\hline Film & $\mathrm{a}_{\mathrm{w}}$ Range & n* & \multicolumn{1}{l}{$\mathrm{P}$} & $\mathrm{A}$ & $\mathrm{B}$ \\
\hline CZ & $0.11-0.84$ & 27 & 48.08 & 0.0535 & 0.8618 \\
CZ & $0.53-0.84$ & 15 & 4.52 & 0.0479 & 0.9333 \\
WG & $0.11-0.84$ & 27 & 29.25 & 0.0767 & 0.9900 \\
WG & $0.53-0.84$ & 15 & 2.55 & 0.0707 & 1.0678 \\
WG/SPI & $0.11-0.84$ & 27 & 33.78 & 0.0723 & 0.9850 \\
WG/SPI & $0.53-0.84$ & 15 & 4.40 & 0.0652 & 1.0799 \\
\hline
\end{tabular}

* Number of fitted experimental data points.
(Boquet et al., 1978). Lomauro et al. (1985a, b) concluded that this model fitted sorption data for a considerable number of nuts, oilseeds, spices, coffee and tea products, and vegetables quite well. In a study of moisture adsorption by dried bell peppers at 10,25 , and $40^{\circ} \mathrm{C}$, the Oswin model gave the best fit among several tested mathematical models (Saputra et al., 1989). For the film sorption data of the present study, the Oswin model gave a good fit $(5.24<\mathrm{P}<6.68)$ for the $\mathrm{a}_{\mathrm{w}}$ range between 0.11 and 0.58 (table 6). The fit on the whole isotherm curves was poor $(\mathrm{P}=10-20)$.

Use of the Halsey model was recommended for meats, milk products, and vegetables (Boquet et al., 1978). According to Lomauro et al. (1985b), the same model successfully applied to water sorption data for several nuts, oilseeds, and starchy foods. Iglesias et al. (1975) and Iglesias and Chirife (1976) found that Halsey's model could be used to describe reasonably well the sorption behavior of 69 different food materials in the approximate $a_{w}$ range of 0.10 to 0.80 . Ayranci et al. (1990) reported good fit of the Halsey model to sorption isotherms of dried apricots, dried figs, and raisins. Pixton and Howe (1983) observed a good fit of the Halsey model to moisture sorption curves of field beans, rice bran, rapeseed, linseed, sunflower seed, dried peas, shelled almonds, and lupins. When fitted to the whole $a_{w}$ range of protein film sorption data in the present study, the Halsey model showed a very poor fit. However, Halsey's model showed an excellent fit $(\mathrm{P}=2.55,4.40$, and 4.52 for $\mathrm{WG}, \mathrm{WG} / \mathrm{SPI}$, and $\mathrm{CZ}$ films, respectively) at the high $\mathrm{a}_{\mathrm{w}}(0.53$ to 0.84$)$ portion of the film isotherms (table 7).

\section{CONCLUSIONS}

It was demonstrated in the present study that the GAB moisture sorption isotherm model can be successfully applied to moisture adsorption by grain protein films in the water activity range between 0.11 and 0.84 . Other models are of value when applied on specific portions of the grain films' adsorption isotherms. The Smith and Halsey models can be used within the high water activity range of 0.53 to 0.84 , whereas the Oswin model can be used within the low water activity range of 0.11 to 0.58 .

ACKNowledgment. This research was supported by a South Carolina Agricultural Experiment Station Enhancement in Packaging Research Competitive Grant.

\section{REFERENCES}

Aydt, T. P., C. L. Weller and R. F. Testin. 1991. Mechanical and barrier properties of edible corn and wheat protein films. Transactions of the ASAE 34(1):207-211.

Ayranci, E., G. Ayranci and Z. Dogantan. 1990. Moisture sorption isotherms of dried apricot, fig and raisin at $20^{\circ} \mathrm{C}$ and $36^{\circ} . C . J$. Food Sci. 55(6): 1591-1593, 1625.

Becker, H. A. and H. R. Sallans. 1956. A study of the desorption isotherms of wheat at $25^{\circ} \mathrm{C}$ and $50^{\circ} \mathrm{C}$. Cereal Chem. 33(2):7991.

Belitz, H. D., R. Kieffer, W. Seilmeier and H. Wieser. 1986. Structure and function of gluten proteins. Cereal Chem. 63(4):336-341. 
Bizot, H. 1984. Using the 'G.A.B.' model to construct sorption isotherms. In Physical Properties of Foods, eds. R. Jowitt, F. Escher, B. Hallström, H. F. T. Meffert, W. E. L. Spiess and G. Vos, 27-41. London, England: Applied Science Publishers.

Boquet, R., J. Chirife and H. A. Iglesias. 1978. Equations for fitting water sorption isotherms of foods. II. Evaluation of various two parameter models. J. Food Technol. 13(4):319327.

Brandenburg, A. H., C. L. Weller and R. F. Testin. 1993. Edible films and coatings from soy protein. J. Food Sci. 58(5):10861089.

Chinnan, M. S. and L. R. Beuchat. 1985. Sorption isotherms of whole cowpeas and flours. Lebensm. Wiss. Technol. 18(2):8388.

Chirife, J. and H. A. Iglesias. 1978. Equations for fitting water sorption isotherms of foods: Part 1 - A review. J. Food Technol. 13(3):159-174.

Chirife, J., E. O. Timmermann, H. A. Iglesias and R. Boquet. 1992. Some features of the parameter $k$ of the GAB equation as applied to sorption isotherms of selected food materials. J. Food Eng. 15(1):75-82.

Gencturk, M. B., A. S. Bakshi, Y. C. Hong and T. P. Labuza. 1986. Moisture transfer properties of wild rice. J. Food Proc. Eng. 8(4):243-261.

Gennadios, A. and C. L. Weller. 1990. Edible films and coatings from wheat and corn proteins. Food Technol. 44(10):63-69. 1991. Edible films and coatings from soymilk and soy protein. Cereal Foods World 36(12): 1004-1009. 1992. Tensile strength increase of wheat gluten films. ASAE Paper No. 92-6517. St. Joseph, Mich.: ASAE.

Gennadios, A., T. H. McHugh, C. L. Weller and J. M. Krochta. 1993a. Edible coatings and films based on proteins. In Edible Coatings and Films to Improve Food Quality, eds. J. M. Krochta and E. A. Baldwin. Lancaster, Pa.: Technomic Publishing Company, Inc. (In press).

Gennadios, A., C. L. Weller and R. F. Testin. 1993b. Modification of physical and barrier properties of edible wheat gluten-based films. Cereal Chem. 70(4):426-429.

. 1993c. Property modification of edible wheat glutenbased films. Transactions of the ASAE 36(2):465-470. . 1993d. Temperature effect on oxygen permeability of edible protein-based films. J. Food Sci. 58(1):212-214, 219.

Gennadios, A., A. H. Brandenburg, C. L. Weller and R. F. Testin. 1993e. Effect of $\mathrm{pH}$ on properties of wheat gluten and soy protein isolate films. J. Agric. Food Chem. 41(11):1835-1839.

Gennadios, A., H. J. Park and C.L. Weller. 1994. Relative humidity and temperature effects on tensile strength of edible protein and cellulose ether films. Transactions of the ASAE 36(6): 1867-1872.

Gontard, N., S. Guilbert and J-L. Cuq. 1992. Edible wheat gluten films: I. Influence of the main process variables on film properties using response surface methodology. J. Food Sci. 57(1):190-195, 199.

1993. Water and glycerol as plasticizer affect mechanical and water vapor barrier properties of an edible wheat gluten film. J. Food Sci. 58(1):206-211.

Guilbert, S. 1986. Technology and application of edible protective films. In Food Packaging and Preservation. Theory and Practice, ed. M. Mathlouthi, 371-394. London, England: Elsevier Appl. Science Pub. Co. 1988. Use of superficial edible layer to protect intermediate moisture foods: Application to the protection of tropical fruit dehydrated by osmosis. In Food Preservation by Moisture Control, ed. C. C. Seow, 199-219. London, England: Elsevier Appl. Science Pub. Co.
Halsey, G. 1948. Physical adsorption of non-uniform surfaces. J. Chem. Phys. 16(10):931-937.

Iglesias, H. A., J. Chirife and J. L. Lombardi. 1975. An equation for correlating equilibrium moisture content in foods. J. Food Technol. 10(3):289-297.

Iglesias, H. A. and J. Chirife. 1976. A model for describing the water sorption behavior of foods. J. Food Sci. 41(5):984-992.

Kester, J. J. and O. R. Fennema. 1986. Edible films and coatings: A review. Food Technol. 40(12):47-59.

Krochta, J. M. 1992. Control of mass transfer in foods with edible coatings and films. In Advances in Food Engineering, eds. R. P. Singh and M. A. Wirakartakusumah, 517-538. Boca Raton, Fla.: CRC Press Inc.

Labuza, T. P. 1968. Sorption phenomena in foods. Food Technol. 22(3):263-272.

1984. Moisture Sorption: Practical Aspects of Isotherm Measurement and Use. St. Paul, Minn.: American Association of Cereal Chemists.

Lomauro, C. J., A. S. Bakshi and T. P. Labuza. 1985a. Evaluation of food moisture sorption isotherm equations. Part I: Fruit, vegetable and meat products. Lebensm. Wiss. Technol. 18(2):111-117.

1985b. Evaluation of food moisture sorption isotherm equations. Part II: Milk, coffee, tea, nuts, oilseeds, spices and starchy foods. Lebensm. Wiss. Technol. 18:118-124.

Oswin, C. R. 1946. The kinetics of package life. III. Isotherm. J. Chem. Ind. 65:419-421.

Park, J. H. and M. S. Chinnan. 1990. Properties of edible coatings for fruits and vegetables. ASAE Paper No. 90-6510. St. Joseph, Mich.: ASAE

Pixton, S. W. and R. W. Howe. 1983. The suitability of various linear transformations to represent the sigmoid relationship of humidity and moisture content. J. Stor. Prod. Res. 19(1):1-18.

Saputra, D., G. M. White and F. A. Payne. 1989. Adsorption equilibrium moisture relationship of dried bell peppers. ASAE Paper No. 89-6509. St. Joseph, Mich.: ASAE.

SAS Institute, Inc. 1988. SAS/STAT ${ }^{\mathrm{TM}}$ User's Guide. Release 6.03 Ed. Cary, N.C.

Shewry, P. R. and B. J. Miflin. 1985. Seed storage proteins of economically important cereals. In Advances in Cereal Science and Technology, Vol. 7, ed. Y. Pomeranz, 1-83. St. Paul, Minn.: American Association of Cereal Chemists Inc.

Smith, S. E. 1947. The sorption of water vapor by high polymers. J. Am. Chem. Soc. 69(3):646-651.

Trezza, T., H. J. Park, C. L. Weller, R. F. Testin and P. J. Vergano. 1992. Barrier properties of cellulosic and zein films for use as food packaging. Paper No. 430. Presented at Annual Meeting of Institute of Food Technologists, New Orleans, La., 20-24 June.

Tsami, E., D. Marinos-Kouris and Z.'B. Maroulis. 1990. Water sorption isotherms of raisins, currants, figs, prunes and apricots. J. Food Sci. 55(6):1594-1597, 1625.

Watt, I. C. 1983. The theory of water sorption by biological materials. In Physical Properties of Foods, eds. R. Jowitt, F. Escher, B. Hallström, H. F. T. Meffert, W. E. L. Spiess and G. Vos, 27-41. London, England: Applied Science Publishers.

Wolf, W., W. E. L. Spiess, G. Jung, H. Weisser, H. Bizot and R. B. Duckworth. 1984. The water-vapour sorption isotherms of microcrystalline cellulose (MCC) and of purified potato starch. Results of a collaborative study. J. Food Eng. 3(1):5173.

Young, J. H. 1976. Evaluation of models to describe sorption and desorption equilibrium moisture content isotherms of Virginiatype peanuts. Transactions of the ASAE 19(1):146-150, 155. 